\title{
Nemzeti innovációs rendszerek a visegrádi országokban
}

\author{
Lux Gábor
}

KRTK Regionális Kutatások Intézete

\section{A TANULMÁNY CÉLJA}

Jelen tanulmány a visegrádi országcsoport nemzeti innovációs rendszereiről, és a kialakuló innovációpolitikai eszköztár fejlődéséről nyújt összehasonlító elemzést. A vizsgálatok fő célja a fejlődés közös vonásainak megragadása, és a nemzeti, regionális szintű különbségeket is ebböl a perspektívából vizsgálja.

\footnotetext{
ALKALMAZOTT MÓDSZERTAN

A tanulmány az elérhető nemzetközi szakirodalom feldolgozásán és szintézisén alapul, amelyet alapvető összehasonlító statisztikákkal egészítettem ki.
}

\section{LEGFONTOSABB EREDMÉNYEK}

A visegrádi országok innovációs rendszerei stagnáló vagy lemaradó teljesítményt nyújtanak a vezető innovátorokhoz képest. Nem csak az állami, hanem az üzleti innováció intézményei is gyengék, amelyre a térség országaira jellemző függő piacgazdasági modell is hatással van. A belső innovációs kapacitások gyengék, jócskán elmaradnak a globális élvonaltól. Ugyanakkor az innovációpolitikai eszközrendszer is alacsony hatékonyságú, a felzárkóztatási szemlélet helyett a már eleve sikeres innovátorokat juttatja többletelőnyökhöz. A regionális és lokális szint gyengesége területi polarizációs folyamatokat eredményez, de a modell egésze is jelentős illeszkedési problémákat vet fel, konzerválódik a fejlettségi rés a térség egésze és az európai magországok között.

\section{GYAKORLATI JAVASLATOK}

Az innovációs politikáknak a reális szükségletekhez alkalmazkodó, a hazai vállalkozások felzárkózását szolgáló, eltérő szükségletekhez idomuló és térben is differenciált támogatásokra érdemes fókuszálniuk.

Kulcsszavak: innováció, nemzeti innovációs rendszer, tudásalapú gazdaság, regionális innovációs rendszer

Köszönetnyilvánitás: Jelen publikáció az Európai Unió, Magyarország és az Európai Szociális Alap társfinanszírozása által biztosított forrásból az EFOP-3.6.2-16-2017-00017 azonosítójú „Fenntartható, intelligens és befogadó regionális és városi modellek" címủ projekt keretében jött létre.

DOI: 10.15170/MM.2020.54.KSZ.I.04 


\section{BEVEZETÉS INTRODUCTION}

A modern innováció jelenségét az elfogadott szakirodalom többdimenziós, interaktív folyamatként írja le, amely egyben rendszereket is alkot. A nemzeti innovációs rendszerek kapcsán a kutatók két stilizált tényből indulnak ki: abból, hogy 1) a nemzetgazdaságok innovációs teljesítménye között rendszerszerü, nemzeti szintủ különbségek mutathatók ki, és 2) ez részben az eltérő technológiai és innovációs kapacitásoktól, részben a támogató intézményrendszerek állapotától függ (Filippetti \& Archibugi 2011). Lundvall a rendszer elemei közötti kölcsönhatások jelentőségét hangsúlyozza: nem csak kapacitásokról, hanem nehezen megfogható kapcsolatokról és folyamatos interakcióról is szó van (Lundvall 1992, Asheim et al. 2011). A tudás térben korlátozott áramlásokkal leírható, kutatók-mérnökök közötti interakciók révén terjedő, és így területi különbségeket alakító szerepét hangsúlyozza Varga (2009) is. Az innovációk ,új kombinációkat" eredményeznek, vagyis a rendszer maga stabil és folyamatos, de outputjai jelentős újdonságot képviselnek. Az interaktív tanulás különböző intézményrendszerekben valósul meg - bizonyos intézményi konfigurációk pedig hatékonyabb tanulási folyamatokat tesznek lehetővé, és rendszeresen több, vagy jelentősebb innovációk létrejöttét segítik elő (Lundvall et al. 2002).

Az innovációs rendszerek több földrajzi léptékben működnek. A nemzetközi kutatások elsősorban a nemzeti és regionális innovációs rendszerekre (NIS/NSI - National Innovation System, RIS Regional Innovation System) összpontosították figyelmüket, de mellettük kisebb mértékben a lokális szintet (LIS) elemző vizsgálatokra is sor került. Különösen jelentős a helyi szint a társadalmi töke és a lokalizált tudástermelés kapcsán, amelyek kulcsfontosságúak egyes régiók innovációs aktivitásában (Asheim 1999). A fejlett országokban a szélesebb innovációs rendszerek elsősorban mégis regionális keretek között értelmezhetők, általában több csomópontot fognak össze egy koherens rendszerben. Ezt a rendszert egyszerre jellemzi az agglomeráció és a lokalizáció.

A RIS megközelítés számos problémába ütközik Közép-Európa posztszocialista országaiban: az erős külgazdasági függés, az innovációs kapacitások széttöredezettsége, a gyenge adszorpciós képesség korlátokat szab a RIS-koncepció alkalmazásának (Květoň - Horák 2018), s ezeket erősítik a centralizált államszervezésből eredő intézményi gyengeségek, kapacitáshiányok is. De elméleti hiá- nyossáról is beszélhetünk, hiszen a szakirodalmi vitákat elsősorban fejlett országok sikeres (gyakran egyedi versenyelőnyökből profitáló) mintatérségeiről kézült elemzések uralják; lényegesen kevesebb munka született a perifériák lehetőségeiről. Mivel ez a feladat lényegesen meghaladná egy folyóiratközlemény terjedelmi és koncepcionális korlátjait, e tanulmány célja a szintézis: a visegrádi országok nemzeti és regionális innovációs rendszereiben beazonosítható közös vonások megragadása. Ehhez a (föként nyugati) szakirodalomban azonosítható ideáltípus és a valóság közötti különbségek kiemelésével jutunk el, amely a tanulmány végén elméleti és szakpolitikai következtetések megfogalmazására ad lehetőséget.

\section{INNOVÁCIÓS RENDSZEREK A RENDSZERVÁLTÁS UTÁN INNOVATION SYSTEM AFTER TRANSFORMATION}

A közép-európai innovációs rendszerek fejlődési útját a piacgazdasági átmenet közös feltételrendszere határozza meg. Az államszocializmus innovációs intézményei a modern innovációs szakirodalomban elvárt szerepüket nem, vagy csak korlátozottan töltötték be, posztszocialista átalakulásuk pedig jelentős transzformációs veszteségekkel járt (Gál - Schmidt 2017). Az alkalmazott kutatás vállalati és állami intézményeit jobbára felszámolták (Magyarországon, Lengyelországban és Szlovákiában) vagy privatizálták (Csehországban); a fennmaradó intézmények müködése a rövid távú túlélésre összpontosult, amely csak kisméretü projektek véghezvitelére adott lehetőséget (Žižalová 2010, Woodward et al. 2012, Marek \& Blažek 2016). Ha az innováció hatékonysága kapcsán európai paradoxonról, vagyis az erős tudástermelés - gyenge tudásalkalalmazás kettőséről beszélünk (Dosi et al. 2006), akkor mellette egy közép-európai innovációs paradoxon is figyelmet érdemel: a rendszerváltó országok pont azokban az években mondtak le (külső kényszereknek engedelmeskedve, de akarva-akaratlanul finanszírozási prioritásokat felállítva) $\mathrm{K}+\mathrm{F}$ kapacitásaik és alkalmazott kutatásuk számottevő részéről, amikor a tudásalapú gazdaság ideája világszerte teret nyert, és a gazdasági sikerek általánosan elismert útjává emelkedett.

Jelentősen visszaesett az innováció egyik legkönnyebben megragadható mérőszáma, a szabadalmaztatási tevékenység (v.ö. Varga 2009). Lengyelországban 1990 és 2000 között éves átlagban mindössze 18 szabadalmi bejelentést tettek, és az érték 2006-ban is alig érte el a 
százat - összehasonlításként: Németországban évente 25 ezer, Franciaországban nyolcezer, Svájcban ötezer bejelentés született (Klonowski 2012). Az innovációs aktivitásban a modern húzóágazatok (ICT-technológiák, biotechnológia) semmiféle szerepet nem játszottak; a legmagasabb innovációs aktivitás a hagyományos iparágakban alakult ki (Woodward et al. 2012). Szlovákia statisztikái még kedvezőtlenebbek: 2005-2015 között összesen 70 szabadalmi bejegyzés született az országban (Braha et al. 2015). 2012-ben az EU28 országokban egymillió munkavállalóra átlagosan 225,2 szabadalmi bejelentés esett; Csehországban azonban csak 35,8, Magyarországon 45,2, Lengyelországban 26,9, Szlovákiában mindössze 19,1. Szlovénia 84,4-es értéke a legmagasabb a posztszocialista országok között; Románia $(3,6)$ és Bulgária $(5,6)$ uniós sereghajtók.

Az innovációs folyamatot a térség összes országában a külföldi nagyvállalatok uralják. Klonowski (2012) adatai szerint a termelö nagyvállalatok innovációs kiadásai ötszörösen meghaladták a KKV-szektorét - ellentétben a nyugati állapotokkal, ahol az innovációk zöme kis- és középvállalatokhoz köthető. Nem csak a kapacitások hiányoznak azonban, hanem az innovációs rendszer belső kapcsolatai is gyengék: a hazai tulajdonú vállalatok általában bizalmatlanabbak, kooperációs aktivitásuk gyengébb a nyugatinál. Ahol megvannak az innovációs kapcsolatok, ott elsősorban beszállítókkal, vevőkkel és más vállalatokkal alakultak ki, és sokkal kevésbé a felsőoktatással vagy kutatással (Woodward et al. 2012, Dzikowski 2015). A legygyakoribb innovációs formák nem technológiai, hanem szervezeti, termékminőséghez kötődő innovációk, amelyeket csak ritkán kombinálnak erős technológiai elemekkel (Gołebiowski \& Lewandowska 2015). A szervezeti innovációk elsősorban a közepes és alacsony technológiai intenzitású iparágakban voltak alkalmasak a külpiaci sikeresség javítására; miközben a high-tech iparágakban aktív vállalatok elsősorban a marketing- és termékinnovációra helyezték a hangsúlyt.
A külföldi tulajdonú vállalatok termelési rendszerei általában nem igénylik a lokális innovációtartalmat, hiszen azt külső forrásból, a globális centrumtérségek fejlesztő laboratóriumaiból szerzik meg. A valóság ennél valamivel összetettebb: az elmúlt évtizedben megjelent, majd növekedett a gyakorlati, „futószalag melletti” innováció szerepe (Domański \& Gwosdz 2009). Marek és Blažek (2016) a külföldi müködőtőkéhez (KMT) kötődő innováció alacsony területi beágyazottságára hívják fel a figyelmet. Ugyanakkor a kisebb méretü, jellemzően rosszabb tényezőellátottságú hazai iparvállalatok is elsősorban inkrementális innovációt valósítanak meg; eredményeik gyakran csak saját maguk és szük környezetük számára jelentenek újdonságot, ezért nem könnyen piacosíthatók (Žižalová 2010, Klonowski 2012, Mazur \& Zaborek 2015). A ,hazai” és „befektető” országok vállalatai közötti technológiai rés önmagában befolyásolja az innovációtranszfer lehetőségeit (spilloverek, abszorpciós kapacitás); a nagyvállalatok és KKV-k közötti kapcsolati háló ritkás.

A rendszerváltások dezintegrációját követő innovációs politikák az ezredforduló előtti években jelentek meg ismét markánsan a visegrádi országok közpolitikáiban. Ezek az eszközök és intézmények már beleilleszkednek a nyugati modellekbe, mivel azok adaptációiként jöttek létre, politika- és gyakran forrástranszfer formájában jelentek meg (Lubos 2015). Az Európai Unió közvetve, példaként is lebegett a rendszerváltó országok előtt, de maga is tevékenyen szerepet vállalt a befektetési és innovációs politikák formálásában (Medve-Bálint 2014). Ez az adaptáció (az innováció „,európaiasitása”) önmagában is egy kívülről importált általános modellt képvisel, amely óhatatlanul illeszkedési problémákat vet fel; a nemzeti és EU-s innovációpolitikák forrásainak aránytalansága pedig egyértelműen az utóbbi felé billentik a mérleget. (Az EU-15-ök addicionális nemzeti forrásai lényegesen bővebbek és széleskörübbek.) 
1. ábra: A tudásalapú gazdaság indexei Közép- és Délkelet-Európában (2018, 1-10)

Figure 1. Knowledge economy indices in Central and South-Eastern Europe (2018, 1-10)

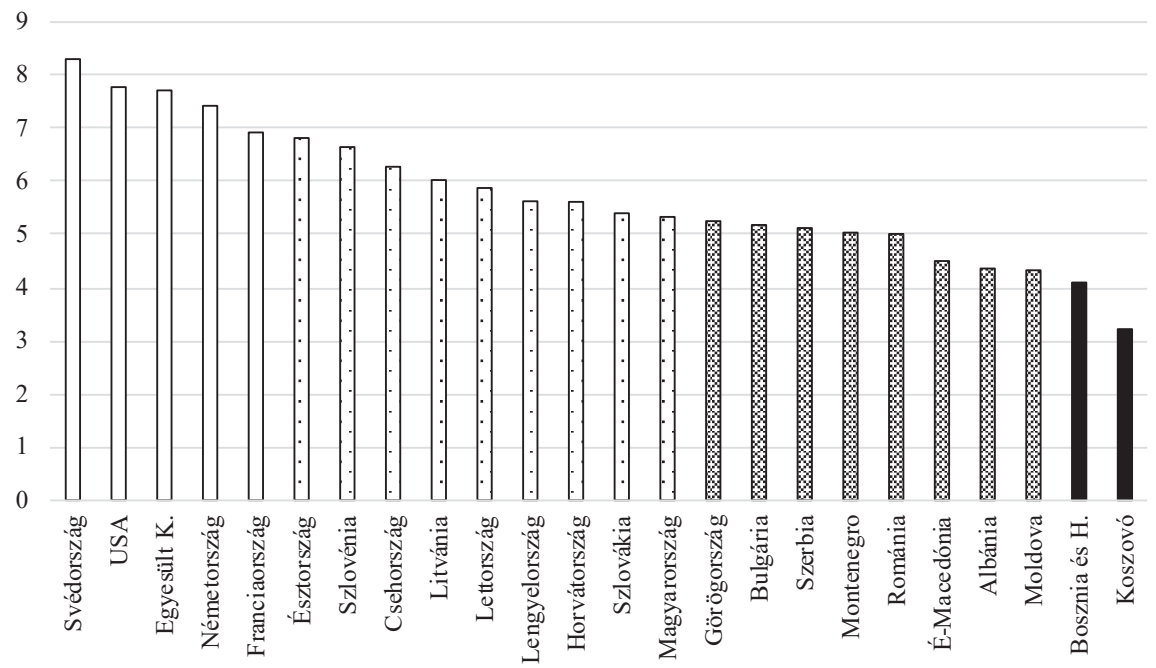

Jelmagyarázat: A fehér oszlopok a fejlett OECD-tagállamokat, a pontozott oszlopok a magasan, a rácsozott oszlopok a közepesen fejlett, a fekete oszlopok a korai stádiumú tudásalapú gazdasággal rendelkezö államokat jelzik.

Forrás: EBRD adatai alapján saját szerkesztéS

Közhelyszerü jelenség a posztszocialista országok gyenge szereplése az innovációs statisztikákban, így az EU jelentéseiben, az Európai Újjáépítési és Fejlesztési Bank (EBRD) tudásgazdasági indexében, a Global Entrepreneurship Index (GEI, Szerb - Trumbull 2015), a Global Innovation Index (GII), vagy a European Innovation Scoreboard (2018) rangsoraiban - ezek az elemzések más-más hangsúlyokkal, de nagyjából hasonló képet adnak térségünkröl. Az EBRD összehasonlító adatai alapján látható, hogy a posztszocialista országok földrajzilag aránylag jól lehatárolható fejlettségi csoportokat alkotnak, amelyekben Csehország, Szlovénia és Horvátország mutatnak aránylag kedvezőbb teljesítményt környezetükhöz képest (1. ábra).

A European Innovation Scoreboard 2010 és 2017 közötti adatai a közép-európai országok stagnálását vagy lemaradását jelzik; az OECD 2011 és 2018 közötti összehasonlítása szerint az alacsony bázisról induló Szerbiát és Albániát leszámítva Lettország és Észtország teljesítményének javulása volt magasabb, Lengyelországé és Magyarországé alacsonyabb. A fejlödési folyamatok elfedik a valódi problémát: ebben az időszakban konzerváló- dott a keleti és nyugati országok közötti innovációs rés; az általános mutatókon túl az innovációs rendszerek alkotóelemeit mérő részindexek is a mezőny második felében, a déli tagállamok társaságában helyezték el a térség országait. A lemaradás aránylag csekélyebb volt az emberi erőforrások, az innovációbarát környezet, a vállalati beruházások és a foglalkoztatási hatások terén, és súlyosabb a kutatási rendszerek vonzereje, a finanszírozás, s legsúlyosabban az innovatív szervezetek és ezek outputjai esetében. Megállapítható, hogy a közép-európai országok meglévö potenciáljukat is gyengébben aknázták ki, mint azt meglévő kutatási kapacitásaik indokolták volna.

A nemzeti innovációs rendszerek hatékonysági különbségei mögött további résztényezök állnak. Egy cseh-szlovák-magyar kutatás (Prokop et al. 2017) eredményei szerint a 2010-es évek első felében Magyarországon müködött a leghatékonyabb innovációs rendszer, vagyis az innovációs inputokat itt sikerült legjobban outputokká konvertálni, az uniós forrásokat hatékonyan felhasználni, és a magyar vállalatok voltak képesek legjobban megragadni a külső $\mathrm{K}+\mathrm{F}$ eredményeket is. Csehország- 
ban az összetett inputkombinációk eredményeztek jobb outputokat. Itt a külső források szerepe nem volt jelentős a feldolgozóipar eredményeiben; sem a nemzeti, sem az uniós források felhasználása nem volt hatékony. Szlovákiában csekély számú kombináció generálta a kedvező, de a két másik vizsgált országnál gyengébb outputokat. A másik két országhoz képest itt nem volt szerepe a vállalkozások belső $\mathrm{K}+\mathrm{F}$ aktivitásának sem; a szlovákiai vállalatok hatékonysága tehát más tényezőkön (elsősorban vállalkozói készségeken) alapult. A nemzeti szintü eltéréseken kívül a vizsgálat egyik lényeges tanulsága, hogy a termelési tényezök (inputok) megfelelö kombinációi és a hatékony támogatások kulcsfontosságúak a jó outputok eléréséhez: vagyis mind az alapvető adottságok, mind az intézményi háttér lényeges szerepet játszik az innováció hatékonyságának alakulásában.

\section{AZ INNOVÁCIÓPOLITIKAI ESZ- KÖZRENDSZER FEJLŐDÉS THE DEVELOPMENT OF THE INNOVATION POLICY TOOLKIT}

Az innovációpolitikák visegrádi országok nemzeti eszközrendszerében számos közös pont található, fejlödésüket közös jegyek kötik össze. Általában érvényesültek Jasinski (2014) Lengyelországra tett megállapításai: a térség országai elsősorban pénzügyi eszközökkel éltek, kínálatoldali felfogást követtek, nem differenciáltak a kis- és nagyvállalatok között (és nem emelték ki külön a high-tech szektort), és több figyelmet fordítottak az új tudományos eredményekre, mint azok megvalósítására vagy elterjesztésére. Az aktív, kiterjedt innovációs politikák kialakulása az ezredfordulóig váratott magára, és uniós hatásokat tükrözött.

A támogatottak között szélesedő hatékonysági rés figyelhető meg. A nem megfelelően célzott eszközök kihasználtsága alacsony, és nem azokhoz jutnak el, akik valóban nagyot lépnének elöre a segítségükkel. Több tanulmány (Woodward et al. 2012, Jasinsky 2014, Dzikowski 2015) azt mutatja, hogy a támogatások nehezen hozzáférhetők, gyakran nem is ismertek a vállalatok előtt. A támogatások elosztása nem felzárkóztatási, hanem kiválósági szempontokat követ, és az eleve jól teljesítö, általában nagyobb vállalatokat juttatja többletforrásokhoz.

$\mathrm{Az}$ innovációpolitikák két generációjának eredményeire és az uniós politikák változásaira reflektálva a 2010-es évek közepétől jelentős változásokat tapasztalunk a nemzeti innovációs rendszerek irányításában. Nagyobb szerepet kapott a gyakorlati innováció a „tiszta” K+F-fel szemben; a közpénzek mellett a magánforrások jobb bevonására törekedtek. A külső innováció abszorpciójáról növekvő hangsúly került a belső innovációs képességek fejlesztésére (Lubos 2015, Marek \& Blažek 2016, Mroczkowski \& Miller 2017). A lengyel innovációpolitikát összefogó Morawiecki-terv szakít az illuzórikus „mindenre jó” fejlesztési receptekkel (,nano-bio-techno" projektek), és a RIS-projektekben az EU intelligens specializációs eszközeire támaszkodik. Az egyetemek szerepét erősebb lokális beágyazódásukban látja, elősegítve a regionális és helyi Triple Helixalapú együttmüködések kialakulását. Ez a szemléletváltás a többi visegrádi országban még korábbi fázisban van.

$\mathrm{Az}$ elmúlt évtizedben bevezetett intelligens specializációs (S3) stratégiák elméletileg jó feltételeket biztosítanak arra, hogy a nem élvonalbeli térségek is megtalálják a fejlődésüket támogató alkalmazott innovációs pályákat. Elvetik a „mindenre alkalmazható" (de jobbára csak a globális centrumtérségekben sikeres) fejlesztési recepteket, és a specifikus, lokalizált tényezőkre összpontosítanak (Vallance et al. 2018). Az S3 stratégiákhoz illeszkedő programok az innováció korai, kísérletező fázisára, a gazdasági szereplők ,kereső magatartására" fókuszálnak, és végső soron a meglévő képességek „új kombinációival” új termékek, eljárások létrehozására törekednek (ebben hasonlítanak a tanuló régiók korábbi koncepciójára). Ugyanakkor az S3-típusú innovációs politikák hatékonyságát is gyengíti, hogy a visegrádi országok ipari térségei gyakran nem rendelkeznek olyan erőforrásokkal vagy vállalkozói ökoszisztémával, amelyek ezeket a programokat sikerre vihetnék.

Az intelligens specializáció nem egyedüli képviselője az új innovációs formáknak. Egyre több jele van a felhasználókat az innovációs folyamatba és termékfejlesztésbe bevonó nyílt innováció (Open Innovation, OI) meghonosodásának. Az OI koncepció gyakran alapul eltérő területek eredményeinek összekapcsolásán; elsősorban a szolgáltató ágazatokra jellemző, de egyes ipari tevékenységekben is meggyökerezett. A fejlesztéspolitika ezért elsősorban hálózatépítéssel, az interakciók tereinek létrehozásával segítheti elő új tudáskombinációk létrejöttét - akár „virtuális intézetek” létrehozásával, a jelentős tudományos központok környezetében (Mazur \& Zaborek 2015, Mroczkowski \& Miller 2017).

Sajátos helyzetet foglal el az innováció finanszírozásában a kockázati töke. Kialakulása lassan ment végbe, és a 2000-es évek második feléig nem játszott jelentős szerepet. Az EU-csatlakozás után Lengyelországban az alacsony bázisról 
aránylag gyors felfutás ment végbe (Weresa 2015). A másik három országban a folyamat lassabb és jóval kevésbé kiterjedt a fejlett tökepiaccal rendelkező Lengyelországnál. Mindenhol él azonban a korábban ismertetett paradoxon: a kockázati tőke sem a high-tech ágazatokban, hanem a hagyományos iparágakban, vagy, mint Magyarország esetében, könnyen kiaknázható szolgáltató ágazatokban összpontosul (Woodward et al. 2012, Lesáková 2014, Šoltés \& Gavurová 2014).

\section{AZ INNOVÁCIÓS RENDSZEREK TÉRBELI MÜKÖDÉSE THE REGIONAL OPERATION OF INNOVATION SYSTEMS}

Közhelyszerủ adottság a metropolisztérségek kiemelkedő szerepe az innovációs kapacitások térszerkezetében. Ez a sajátosság az összes visegrádi országban kimutatható (Tödtling et al. 2013, Marek \& Blažek 2016), és részben globális tendenciákat is követ; az eltérés inkább a többi régió gyengeségében ragadható meg. Csehországban az országos kutatási kapacitások felét összpontosító Prága mögött Brno és korlátozottan Ostrava; Lengyelországban Varsó mellett Poznań, Wrocław és a Felső-sziléziai városegyüttes játszik kiemelkedő szerepet (de a további régióközpontok is aránylag erős kapacitásokkal rendelkeznek). Szlovákia és Magyarország egyértelmúen monocentrikus innovációs rendszerrel rendelkezik. Az innovációt támogató intézményrendszer maga is követi ezt a térszerkezetet. A fővárosi centrumok nem csak $\mathrm{K}+\mathrm{F}+\mathrm{I}$ kapacitásokat koncentrálnak, hanem közvetítők is, kapuszerepet látnak el a nemzetközi hálózatok felé (Marek \& Blažek 2016). Ez a közvetítés előnyökkel, ugyanakkor kizárással, mások hozzáférésének de facto akadályozásával is jár. A metropolitánus-nem metropolitánus megosztottság mellett kisebb mértékben a nyugati-keleti fejlődési lejtők és fejlődési tengelyek hatása is kimutatható (Hudec \& Prochádzková 2015).

Bár az innovációs együttmúködések meghatározó kerete a RIS-irodalomban a regionális szint, a közép-európai kutatások megállapításai a nemzeti szint elsőbbségét bizonyítják. A regionális szerepkörü, közepes méretủ egyetemek még nem töltik be a Nyugat-Európában bevett innovációs szerepkört. Müködésük egyoldalúan oktatásorientált, amelyek mellett mérsékelt vállalkozói és technológiatranszfer-aktivitást tanúsítanak (Prónay - Buzás 2016, Peterka et al. 2017, Gál - Ptaček 2018, Huszár et al. 2018). Erdős - Varga (2013), valamint Vallance és tsai (2018) a spinoff-tevékenység gyengeségét is kiemelik: kevés számú, egyedi kivételeket képező vállalatok müködnek, regionális léptékben ma még gyakorlatilag nem mérhető spillover-hatások nélkül. Még kisebb szerepük van a helyi innovációs rendszereknek, annak ellenére, hogy a közép-európai országok ipari versenyképessége elsősorban lokális terekben, és nem egész régiókra kiterjedő rendszerekben jelenik meg (Lux 2017). A lokális innovációs rendszerek kialakulása azonban még az aránylag sikeres regionalizációs folyamaton átesett Lengyelország is korai fejlődési stádiumban van.

$\mathrm{Az}$ innovációpolitikák nem épülnek be megfelelő mértékben a regionális és helyi politikákba. Talán pont gyengeségeikből adódóan pont egyes kisebb központokban fordítottak erre nagyobb figyelmet. Ezek mögött azonban jobbára egyedi tényezők állnak: egy-egy politikai vezetö, helyi összefogás vagy „erős” innovációs ügynökség jelenti azt az eröt, amely képes megfogalmazni és rendszerbe szervezni a törekvéseket. Végső soron a regionális innovációpolitikák hatékonysága jelentősen függ a nemzeti szintủ intézményrendszerektől. Magyarországon az elmúlt években egyértelmüen felülről irányított, teljes mértékben központosított rendszer alakult ki, amelyben nemzeti célok igen, de helyi adottságok alig-alig jelennek meg, míg Lengyelországban két központi ügynökség (Lengyel Vállalkozásfejlesztési Ügynökség, Nemzeti Kutatási és Fejlesztési Központ) mellett - bár vajdaságonként eltérő mértékben - erős és önálló regionális testületek müködnek, amelyek önálló célokat képesek megfogalmazni és keresztülvinni. Csehország és Szlovákia szintén a központosított modellt követik, bár a centrum és a perifériák közötti erőegyensúly Csehországban hazánknál valamivel kedvezőbb, amely a helyi innovációs bázisok erősségéböl ered.

\section{MEGOLDÁSI JAVASLATOK FUTURE PROPOSALS}

A visegrádi országok innovációs rendszereinek fejlődése kedvezőtlen keretfeltételek között, erös külső függőségben zajlott le. Mind a termelő gazdaság, mind az innovációs tevékenységek és politikák működésére rányomja a bélyegét a saját erőforrások hiánya, amelyeket nem ellensúlyoznak a közösségi támogatásokból finanszírozott fejlesztések sem. Ez az egyensúlyhiány és a közösségi forrásoktól való függőség több problémát is felvet (Suurna \& Kattel 2010):

csúcstechnológiai elfogultság: az S3 platformok megjelenése előtti uniós inno- 
vációpolitikák a high-tech ágazatokra összpontosítottak, amelyek a régi tagállamokban összpontosulnak, nem tükrözik a közép-európai országok szükségleteit;

- $\quad$ gyenge illeszkedés: a lokális szempontok (adottságok, képességek és szükségletek) negligálása;

- rövid távú szemlélet és széttöredezettség: a támogatások ,projektesítése" nem fordít kellő figyelmet a hosszú távú innovációs folyamatok, és különösen rendszerfejlesztés szempontjaira.

A visegrádi országok még nem jártak sikerrel az igényeikhez és adottságaikhoz illeszkedő innovációs rendszerek felépítésében. A felmerülö problémák tartósak: a széttöredezettség, a gyenge és gyengén összekapcsolt innovátorok problémája újra és újra felbukkan a térségben.

Hol található a kiút ezekből a problémákból? Ebben a tekintetben nincs szakirodalmi konszenzus. Žižalová (2010) a Triple Helix alapkutatások bázisáról építkező modellje helyett a tanuló régiók inkrementális innovációkat alkalmazó, meglévő kapacitásokból és képességekből építkező fejlődési útját (pl. az S3 fejlesztési filozófiáját) tartja célravezetőnek. Mások egyértelmủen kiállnak a Triple Helix mellett. Rechnitzerrel (2016) és Mroczkowski \& Miller (2017) következtetéseivel egyetérve az ellentétet nem tartom áthidalhatatlannak. A Triple Helixhez kötődő szférák (ipar, kormányzás és tudásbázis) és kapcsolatrendszereik térben lokalizált, térbeli koncentrációs pontokhoz kötődó tényezők, amelynek erősebb beágyazottságára, valamint helyi tartalmának növelésére érdemes törekednünk. Ez azért is fontos szempont, mert az alacsony beágyazottságú tőke esetén erősebb delokalizációs, tőkemozgási kockázatok is jelentkeznek (Tödtling et al. 2013). Minden releváns elméletben közös pontot jelent a minőségi termelési tényezök és a hálózatok, intézmények jelenléte. A posztszocialista országok jellemzően mégis kevésbé érdeklődtek a humántőke-alapú fejlesztések és a hatékony hálózatépítés, mint a fizikai infrastruktúrák iránt (és az uniós fejlesztési programok is nagyrészt erre mutattak).

Különleges figyelmet érdemel az innováció különböző formáinak differenciált értékelése. Az egyes iparágak, eltérő fejlődési szakaszukat élő vállalkozások más-más innovációs szükségletekkel rendelkeznek, és nem a technológiai kiválóság a sikerhez vezető egyetlen út. A külső technológiák, menedzsment-eljárások, szervezeti és inkrementális innovációk integrálása vagy saját erőből történő kifejlesztése számos vállalkozás számára kínál tartós versenyelönyt akkor is, ha ezzel nem alkotnak teljes újdonságot, vagy nem kerülnek az európai élvonalba. Fontos azonban, hogy a nem-technológiai innovációk ne bizonyuljanak ,végzetes vonzerőnek", ne helyettesítői legyenek a termékfejlesztésnek (mintegy ,alacsonyan függő gyümölcsök” gyanánt). A rövid távú sikerek learatása tartósan a technológiai rés további szélesedését, szerkezeti problémák újratermelődését, a regionális rugalmasság és tanulási képesség csökkenését hozza magával. Ezért az innovációpolitikában tévút mind a szüken szabott, lokális adottságokat és igényeket figyelmen kívül hagyó high-tech szemlélet, mind az alkalmazott innováció egyedüli helyességét hangsúlyozó retorika: a jelenlegi igények és a jövőbeli lehetőségek közötti egyensúlyra van szükség. 


\section{HIVATKOZÁSOK REFERENCES}

Asheim, B. (1999), "Interactive Learning and Localised Knowledge in Globalising Learning Economies", GeoJournal, 49, 345-352. DOI:10.1023/A:1007155221758

Asheim, B., Smith, H.L., Oughton, C. (2011), "Regional Innovation Systems: Theory, Empirics, and Policy", Regional Studies, 45(7), 875891. DOI: $10.1080 / 00343404.2011 .596701$

Braha, K., Qineti, A., Serenčéš, R. (2015), "Innovation and Economic Growth: The Case of Slovakia", Visegrad Journal of Bioeconomy and Sustainable Development, 4(1), 7-13. DOI: doi. org/10.1515/vjbsd-2015-0002

Domański, B., Gwosdz, K. (2009), “Toward a More Embedded Production System? Automotive Supply Networks and Localized Capabilities in Poland", Growth and Change, 40(3), 452-482. DOI: $10.1111 / \mathrm{j} .1468-2257.2009 .00490 . x$

Dosi, G., Llerena, P., Labini, M.S. (2006), "The Relationship Between Science, Technologies and Their Industrial Exploitation: An Illustration Through the Myths and Realities of the So-called 'European Paradox', Research Policy, 35(10), 1450-1464. DOI: 10.1016/j. respol.2006.09.012

Dzikowski, P. (2015): "Sources of Information for Innovation and Innovation Activities in the High Technology Sector in Poland", Global Management Journal, 7(1-2), 40-49.

Erdős, K., Varga, A. (2013), "The role of academic spin-off founders' motivation in the Hungarian biotechnology sector", in: João, J.M., Ferreira, M.R., Rutten, R. \& Varga, A. (eds.), Cooperation, Clusters, and Knowledge Transfer. Universities and Firms Towards Regional Competitiveness. New York: Springer, 207-224. DOI:10.1007/978-3-642-33194-7 11

European Innovation Scoreboard (2018), Luxembourg: Publications Office of the European Union.

Filippetti, A., Archibugi, D. (2011): "Innovation in Times of Crisis: National Systems of Innovation, Structure, and Demand", Research Policy, 40(2), 179-192. DOI: 10.1016/j. respol.2010.09.001

Gál, Z., Ptaček, P. (2018), "The Role of MidRange Universities in Knowledge Transfer and Regional Development: The Case of Five Central European Regions", in: Varga, A., Erdős, K. (eds.), Handbook of Universities and Regional Development, Cheltenham: Edward Elgar, 279300. DOI: $10.4337 / 9781784715717.00023$
Gál, Z., Schmidt, A. (2017), "Europe Divided? Can Warsaw Become the Regional Leader of the Central and Eastern European Region?", Politeja, 51(6), 235-260. DOI: 10.12797/ Politeja.14.2017.51.12

Gołebiowski, T., Lewandowska, M.S. (2015), "The Innovation Objectives of Polish Industrial Firms on Their Main Target Markets", in: Weresa, M.A. (ed.), Poland: Competitiveness Report 2015, Warsaw, Warsaw School of Economics Press, 220-239.

Hudec, O., Prochádzková, M. (2015), "Visegrad Countries and Regions: Innovation Performance and Efficiency", Quality Innovation Prosperity, 19(2), 55-72. DOI: 10.12776/qip.v19i2.593

Huszár, S., Prónay, Sz., Buzás, N. (2018), “Az egyetemi kutatók technológiatranszfer-irodákról kialakult véleményének és elvárásainak vizsgálata", Marketing \& Menedzsment, 52(1), 34-46.

Jasinski, A.H. (2014), "Innovation Policy Instruments: Do They Work in Poland?", Int J. Transitions and Innovation Systems, 3(3), 269-290. DOI: 10.1504/IJTIS.2014.065699

Klonowski, D. (2012), "Innovation Propensity of the SME Sector in Emerging Markets: Evidence From Poland", Post-Communist Economies, 24(1), 133-143. DOI: $10.1080 / 14631377.2012 .647633$

Květon, V., Horák, P. (2018), "The Effect of Public R\&D Subsidies on Firms' Competitiveness: Regional and Sectoral Specifics in Emerging Innovation Systems", Applied Geography, 94(5), 119-129. DOI: 10.1016/j. apgeog.2018.03.015

Lesáková, L. (2014), "Evaluating Innovations in Small and Medium Enterprises in Slovakia", Procedia - Social and Behavioral Sciences, 110, 74-81. DOI: 10.1016/j.sbspro.2013.12.849

Lubos, B. (2015), "Polish Innovation Policy Through 2020", in: Weresa, M.A. (ed.): Poland: Competitiveness Report 2015, Warsaw: Warsaw School of Economics Press, 329-341.

Lundvall, B.A. (1992), "National Innovation Systems: Towards a Theory of Innovation and Interactive Learning", London: Pinter.

Lundvall, B.A., Johnson, B., Sloth Andersen, E., Dalum, B. (2002): "National Systems of Production, Innovation and Competence Building", Research Policy, 31(2), 213-231. DOI: 10.1016/S0048-7333(01)00137-8

Lux G. (2017), Újraiparosodás Közép-Európában, Budapest-Pécs: Dialóg Campus Kiadó.

Marek, D., Blažek, J. (2016), "The Challenge of Breaking the Academia-Business Firewall in 
Czechia: Comparing the Role of Differentiated Knowledge Bases in Collaborative R\&D Projects", European Planning Studies, 24(4), 809831. DOI: 10.1080/09654313.2015.1121204

Mazur, J., Zaborek, P. (2015), “Open Innovation in Small and Medium-Sized Polish Firms", in: Weresa, M.A. (ed.), Poland: Competitiveness Report 2015, Warsaw:Warsaw School of Economics Press, 281-306.

Medve-Bálint, G. (2014), "The Role of the EU in Shaping FDI Flows to East Central Europe", Journal of Common Market Studies, 52(1), 35-51. DOI: 10.1111/jcms. 12077

Mroczkowski, T., Miller, M. (2017), "Envisioning Smart Development in Poland from a Triple Helix Systems Perspective: A Critical Assessment of the Morawiecki Plan", Journal of the Knowledge Economy, 8, 513-535. DOI: 10.1007/s13132-017-0486-9

Peterka, S., Juric, P.M., Koprivnjak, T. (2017), "Assessing Entrepreneurial Potential of University: Empirical Evidence from Croatia", Marketing \& Menedzsment, 51(4), 59-70.

Prokop, V., Stejskal, J., Kuvíková, H. (2017), “The Different Drivers of Innovation Activities in European Countries: A Comparative Study of Czech, Slovak, and Hungarian Manufacturing Firms", Ekonomický Časopis, 65(1), 31-45.

Prónay, Sz., Buzás, N. (2016), „Az egyetemi technológia transzfer tevékenység marketing kihívásainak feltárása 6P marketing-mix modell alapján", Marketing \& Menedzsment, 50(1), 4-13.

Rechnitzer J. (2016), A területi töke a városfejlödésben-A Györ-kód. Budapest-Pécs: Dialóg Campus Kiadó.

Šoltés, V., Gavurová, B. (2014), “Innovation Policy as the Main Accelerator of Increasing the Competitiveness of Small and Medium-Sized Enterprises in Slovakia", Procedia - Economics and Finance, 15, 1478-1485. DOI: 10.1016/S22125671(14)00614-5

Suurna, M., Kattel, R. (2010), "Europeanization of Innovation Policy in Central and Eastern Europe", Science and Research Policy, 37(9), 646-664. DOI: 10.3152/030234210X1277811 8264459

Szerb, L., Trumbull, W.N. (2015), "Entrepreneurship and Entrepreneurial Ecosystems in the V4 Countries: The Global Entrepreneurial Index Perspective", Proceedings of the 5th International Conference on Management 2015. Management, leadership and strategy for SMEs competitiveness. Gödöllő: Szent István University Publishing House, 2-7.
Tödtling, F., Asheim, B., Boschma, R., Blažek, J., Žižalová, P., Rumpel, P., Skokan, K., Chládek, P. (2013), "Emerging Regional Innovation Strategies in Central Europe: Institutions and Regional Leadership in Generating Strategic Outcomes", European Urban and Regional Studies, 20(2), 275-294. DOI: 10.1177/0969776411428651

Vallance, P., Blažek, J., Edwards, J., Květoň, V. (2018), Smart Specialization in Regions with Less-developed Research and Innovation Systems: A Changing Role for Universities?", Environment and Planning C: Politics and Space, 36(2), 219-238. DOI:10.1177/2399654417705137

Varga A. (2009), Térszerkezet és gazdasági növekedés, Budapest: Akadémiai Kiadó.

Weresa, M.A. (2015), "Poland's National Innovation System and How It Evolved in 2007 2014", in: Weresa, M.A. (ed.), Poland: Competitiveness Report 2015, Warsaw:Warsaw School of Economics Press, 209-219.

Woodward, R., Wojnicka, E., Pander, W. (2012), Innovation Systems and Knowledge-Intensive Entrepreneurship: A Country Case Study of Poland. CASE Network Studies \& Analyses 446. Warsaw: Centre for Social and Economic Research.

Žižalová, P. (2010), “Geography of Knowledge-Based Collaboration in a Post-Communist Country: Specific Experience or Generalized Pattern?", European Planning Studies, 18(5), 791-814. DOI: 10.1080/09654311003744134 


\section{National Innovation Systems in the Visegrad Countries}

\section{THE AIMS OF THE PAPER}

This paper undertakes a comparison of post-socialist countries on the basis of their national innovation systems, as well as their emerging innovation policies. The main focus of the study is the Visegrad group, with some general remarks concerning Slovenia, the Baltic countries, and South-Eastern Europe.

\section{METHODOLOGY}

The paper is based on a synthesis of available international studies, supplemented with comparative statistics.

\section{MOST IMPORTANT RESULTS}

Innovation systems in the Visegrad countries show a stagnant or lagging dynamic in comparison with leading innovators. In addition to state-financed innovation activity, business innovation also shows considerable weakness, greatly affected by the dominant "dependent market economy" development model. Endogenous innovation capacities are weak, and do not represent the global state-of-the-art. Innovation policy struggles with significant weaknesses and low efficiency. Competitive support schemes redistribute resources to already successful innovators, without encouraging a catching-up process. The weakness of the regional and local tier in public policy leads to the increase of territorial polarisation.

\section{RECOMMENDATIONS}

Innovation policy should meet real demands, with support systems tailored to serve the catching-up of domestic enterprises. Grants should take into account the different needs of different actors, and undertake their activities in a territorially differentiated manner.

Keywords: innovation, National Innovation System, Regional Innovation System, knowledge-based economy

Acknowledgements: This publication/research has been supported by the European Union and Hungary and co-financed by the European Social Fund through the project EFOP-3.6.2-16-2017-00017, titled ,Sustainable, intelligent and inclusive regional and city models”. 